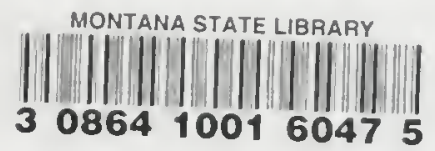

\title{
BIOLOGICAL INTEGRITY \\ OF BIG DRY CREEK AND LITTLE DRY CREEK GARFIELD COUNTY, MONTANA \\ BASED ON THE COMPOSITION AND STRUCTURE OF THE BENTHIC ALGAE COMMUNITY
}

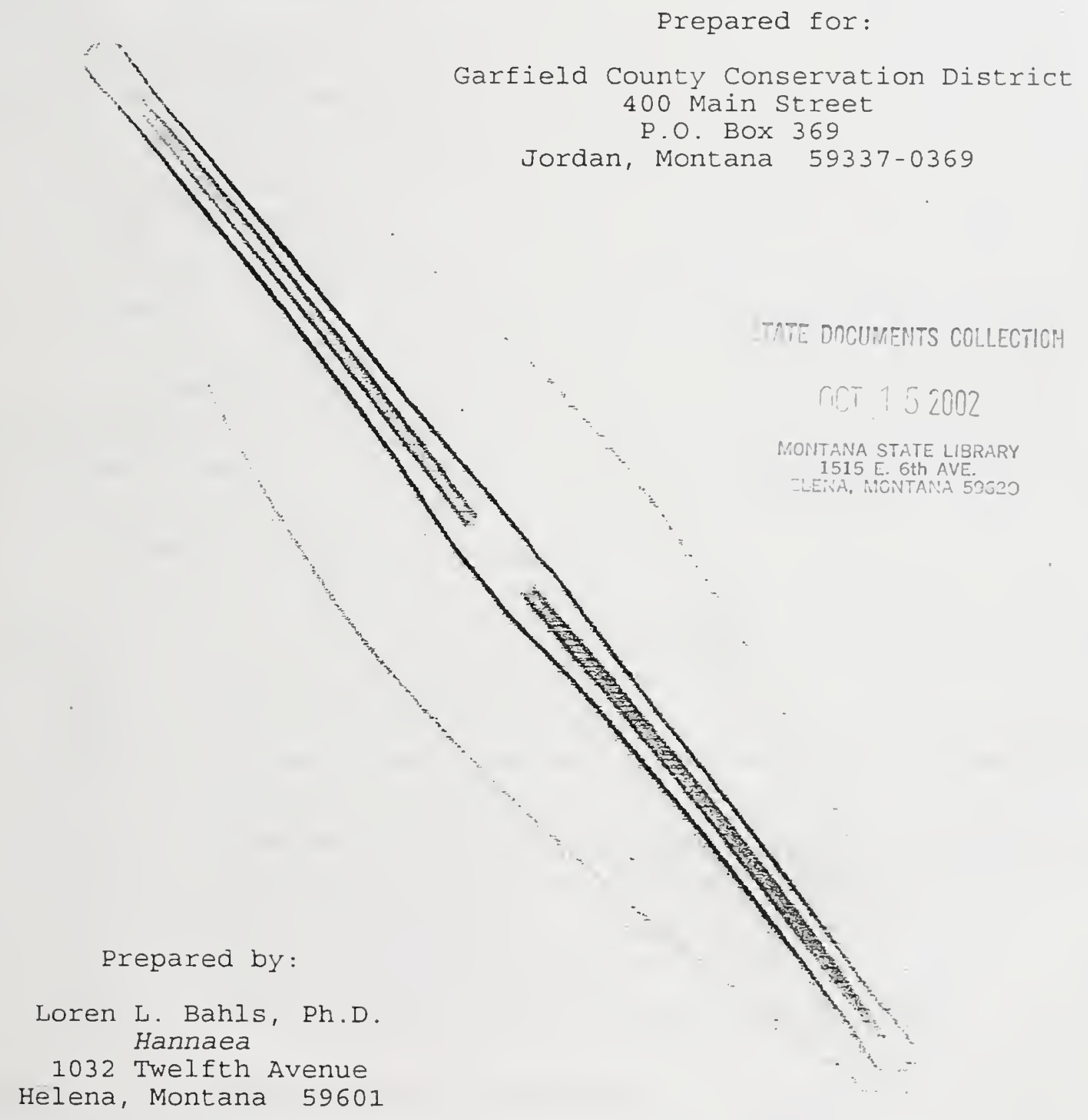

November 14,2000 


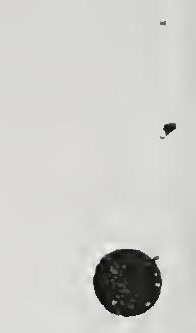

-

- 


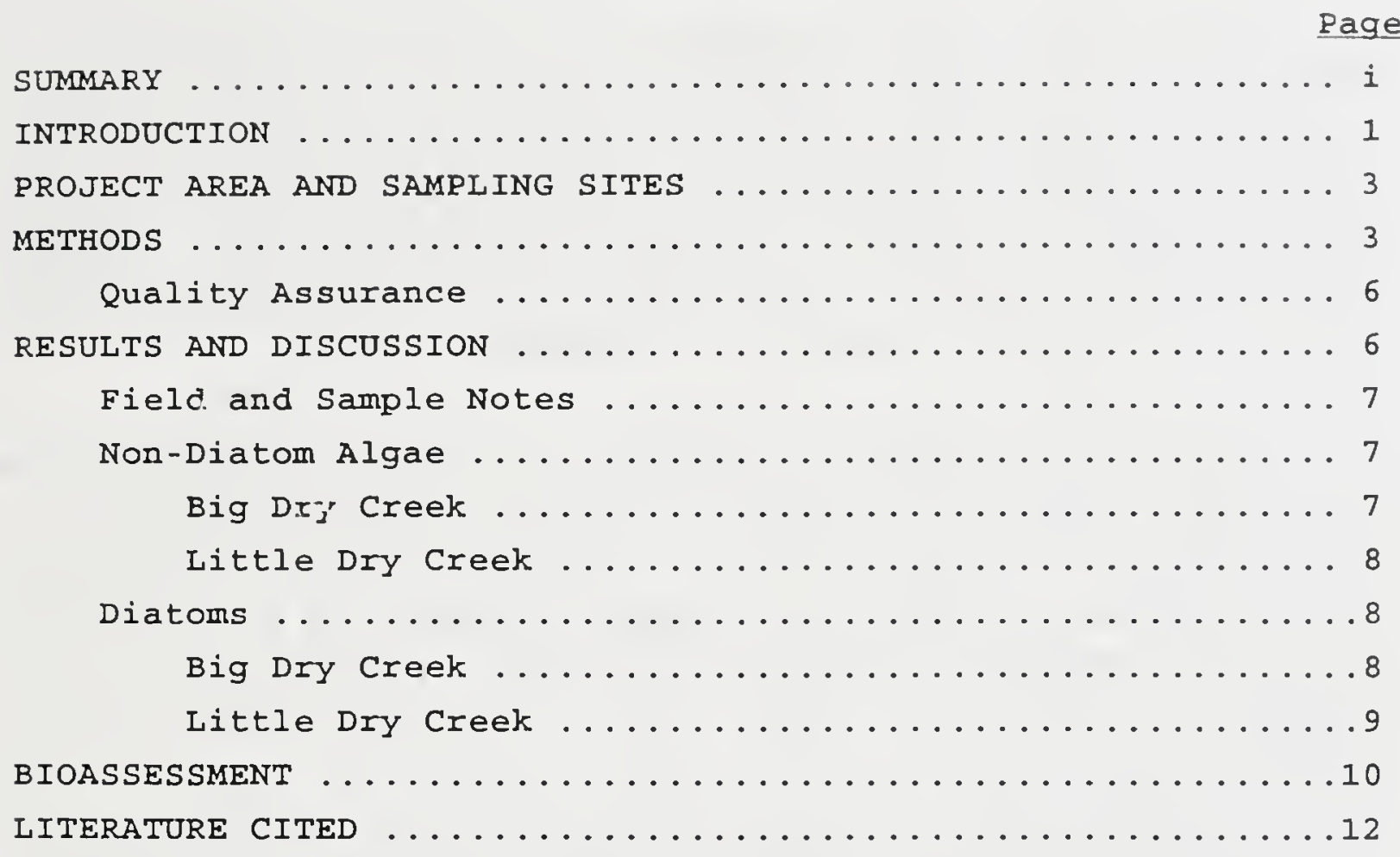

MAPS OF SAMPLING SITES (follow page 14)

\section{TABLES}

Table 1. Location of sampling sites

Table 2. Diatom association metrics

Table 3. Diatom criteria for evaluating biological integrity in prairie streams

Table 4. Abundance of non-diatom algae in Big Dry Creek and Little Dry Creek

Table 5. Major diatom species and diatom metric values for Big Dry Creek and Little Dry Creek

Table 6. Bioassessment of Big Dry Creek (Protocol II)

APPENDIX A: DIATOM PROPORTIONAL COUNTS 


\section{SUMMARY}

Composite periphyton samples were collected from natural substrates in lower Big Dry Creek and lower Little Dry Creek in eastern Garfield County, Montana. Samples were collected following standard operating procedures of the Montana Department of Environmental Quality, processed and analyzed using standard methods for periphyton, and evaluated following modified USEPA rapid bioassessment protocols for wadeable streams.

Most diatom association metrics indicated that Big Dry Creek haci good to excellent biological integrity when compared to least-impaired reference streams elsewhere in eastern Montana. However, a very low pollution index resulted in a rating of fair biological integrity, moderate impairment, and only partial support of aquatic life uses. The low pollution index was the result of excessive organic loading, either from internal sources or from wastewater discharges upstream, or both. The siltation index also indicated problematic conditions in Big Dry Creek.

Potentially toxic blue-green algae were present in Big Dry Creek, but not in sufficient quantities to pose a problem for Iivestock producers.

All diatom metrics indicated full support of aquatic life uses in Little Dry Creek when compared to other prairie streams. only a slightly depressed pollution index resulted in a rating of good rather than excellent biological integrity. Little Dry creek proved to be a suitable local reference stream.

When compared to metric values for Little Dry Creek, the pollution and siltation indexes for Big Dry Creek indicated only minor impairment, good biological integrity, and full support of aquatic life uses. The diatom species diversity index was within the range of no impairment and excellent biological integrity. 


\section{INTRODUCTION}

This report evaluates the biological integrity, support of aquatic life uses, and probable causes of impairment to those uses in Big Dry Creek and Little Dry Creek in Garfield County, Montana. This evaluation is part of an assessment sponsored by the Garfield County Conservation District with assistance from the Natural Resources Conservation Service, U.S.D.A.

The evaluations in this report are based on the structure and species composition of the periphyton or phytobenthos community. The periphyton community is a basic biological component of all aquatic ecosystems. Periphyton accounts for much of the primary production and biological diversity of Montana streams (Bahls et al. 1992).

Periphyton is a diverse assortment of simple photosynthetic organisms called algae, and other microorganisms that live attached to or in close proximity of the stream bottom. Many algae, such as the diatoms, are microscopic. Diatoms are distinguished by having a cell wall composed of opaline glass-hydrated amorphous silica. Diatoms often carpet a stream bottom with a slippery brown film.

Some algae, such as the filamentous greens, are conspicuous and their excessive growth may be aesthetically displeasing. Algae may also deplete dissolved oxygen, interfere with fishing and fish spawning, clog water filters and irrigation intakes, create tastes and odors in drinking water, and generate toxins that may be lethal to livestock and other animals.

Plafkin et al. (1989) and Stevenson and Bahls (1999) list several advantages for using periphyton in biological assessments of streams: 
Algae are universally present in large numbers in all streams and unimpaired periphyton assemblages typically support a large number $(>30)$ of species;

- Algae have rapid reproduction rates and short life cycles, making them useful indicators of short-term impacts;

- As primary producers, algae are most directly affected by physical and chemical factors, such as temperature, nutrients, dissolved salts, and toxins;

- Sampling is quick, easy and inexpensive, and causes minimal damage to resident biota and their habitat;

- Standard methods and criteria exist for evaluating the composition, structure, and biomass of algal associations;

- Identification to species is straightforward for the diatoms, for which there is a large body of taxonomic and ecological literature;

- Excessive algae growth in streams is often correctly perceived as a problem by the public.

- Periphyton and other biological communities reflect the biological integrity ${ }^{2}$ of waterbodies; restoring and maintaining the biological integrity of waterbodies is a goal of the federal Clean water Act;

- Periphyton and other biological communities integrate the effects of different stressors and provide a measure of their aggregate impact; and

- Periphyton and other biological communities may be the only practical means of evaluating impacts from non-point sources of pollution where specific ambient criteria do not exist (e.g., impacts that degrade habitat or increase nutrients).

1 Biological integrity is defined as "the ability of an aquatic ecosystem to support and maintain a balanced, integrated, adaptive community of organisms having a species composition, diversity, and functional organization comparable to that of natural habitats within a region" (Karr and Dudley 1981). 


\section{PROJECT AREA AND SAMPLING SITES}

The project area is located in Garfield county in east central Montana. Big Dry Creek heads at an elevation of 3,500 feet south of sand Springs in the southwestern corner of Garfield county. Little Dry Creek heads south of Jordan at about the same elevation. The two streams flow north and east to where they join 26 miles east of Jordan along Montana Highway 200.

The project area is within the Northwestern Great Plains Ecoregion (Woods et al. 1999). The surface geology of the area consists of sandstone and shales of the Hell Creek formation in the headwaters and near the mouth of Big Dry Creek, and rocks of the coal-bearing Fort Union Formation in between (Renfro and Feray 1972). Upland vegetation is predominantly mixed grassland (USDA 1976). The main land use is livestock grazing.

Periphyton samples were collected at one site each on Big Dry Creek and Little Dry Creek (Table 1). The site on Big Dry Creek (\#9) is about 2 miles upstream from Fort Peck Reservoir on the Missouri River (Map 1). The site on Little Dry Creek (Map 2) is just above its confluence with Big Dry Creek, which is about 8 miles above Site \#9 and 10 miles above Fort Peck Reservoir.

Elevations at the sampling sites are about 2,300 feet for Big Dry Creek and 2,400 feet for Little Dry Creek. Big Dry Creek and Little Dry Creek are classified C-3 in the Montana Surface water Quality standards.

\section{METHODS}

Periphyton samples were collected following standard operating procedures of the Planning, Prevention, and Assistance Division of the Montana Department of Environmental Quality. 
Using appropriate tools, microalgae were scraped, brushed, and/or sucked from natural substrates in proportion to the rank of those substrates at the study site. Macroalgae were picked by hand in proportion to their abundance at the site. All collections of microalgae and macroalgae were pooled into a common container and preserved with Lugol's solution (APHA 1998).

Samples were examined to estimate the relative abundance and rank by biovolume of diatoms and genera of soft (non-diatom) algae according to the method described in Bahls (1993). Soft algae were identified using Dillard (1999), Prescott (1978), Smith (1950), and Whitford and Schumacher (1984). These books also served as references on the ecology of the soft algae, along with Palmer (1977).

After the identification of soft algae, raw periphyton samples were cleaned of organic matter using sulfuric acid, and permanent diatom slides were prepared using Naphrax, a high refractive index mounting medium, following Standard Methods for the Examination of Water and Wastewater (APHA 1998). For each slide, between 401 and 412 diatom cells (802 to 824 valves) were counted at random and identified to species. The following were used as the main taxonomic and autecological references for the diatoms: Krammer and Lange-Bertalot 1986, 1988, 1991a, 1991b; Patrick and Reimer 1966, 1975.

Lowe (1974) was also used as an ecological reference for the diatoms. Bahls et al. (1984) provide autecological information on important diatom species that live in the Fort Union Region of Montana, including many of the diatom species found in Big Dry Creek and Little Dry Creek.

The diatom proportional counts were used to generate an array of diatom association metrics (Table 2). A metric is a characteristic of the biota that changes in some predictable way 
with increased human influence (Barbour et al. 1999).

Metric values for Big Dry Creek and Little Dry Creek were compared to numeric biocriteria developed for streams in the Great Plains Ecoregions of Montana (Table 3). These criteria are based on metric values measured in least-impaired reference streams (Bahls et al. 1992) and on metric values measured in streams that are known to be impaired by various sources and causes of pollution (Bahls 1993).

The criteria in Table 3 distinguish among four levels of impairment and three levels of aquatic life use support: no impairment or only minor impairment (full support); moderate impairment (partial support); and severe impairment (nonsupport). These impairment levels correspond to excellent, good, fair, and poor biological integrity, respectively.

Besides the ecoregional biocriteria listed in Table 3 , metrics for Big Dry Creek were also compared to metrics generated from a local, least-impaired reference stream using Protocol II in Bahls (1993). Little Dry Creek was used as the local, leastimpaired reference stream.

Protocol II is based on the percentage of change in metric values at the study site(s) from values measured at the local reference stream. Criteria for evaluating biological integrity using Protocol II are given in Table 12 in Bahls (1993).

Protocol II may be used if a tributary stream is available that fully supports its aquatic life uses, that is, if it has a rating of "good" or "excellent" biological integrity using Protocol I. Little Dry Creek exhibited only minor impairment using Protocol I and thereby qualifies as a local reference site. 
For Protocol I, only periphyton samples collected in summer (June 21-September 21) can be compared with confidence to reference stream samples because metric values change seasonally and summer is the season in which reference streams and impaired streams were sampled for the purpose of biocriteria development. Protocol II can be used at any time of the year.

\section{QUALTIY ASSURANCE}

Several steps were taken to assure that the study results are accurate and reproducible.

Upon receipt of the samples, station and sample information were recorded in a laboratory notebook and samples were assigned a unique number compatible with the Montana Diatom Database, e.g., 1987-01. The first part of this number (1987) designates the sampling site (Big Dry Creek Site \#9); the second part of the number (01) designates the number of periphyton samples that have been collected at this site to date for which data have been entered into the Montana Diatom Database.

Sample observations and analyses of soft (non-diatom) algae were recorded in a lab notebook along with station and sample information provided by Warren kellogg of the NRCS. A portion of the raw sample was used to make duplicate diatom slides.

On completion of the project, station information, sample information, and diatom proportional count data will be entered into the Montana Diatom Database. One set of diatom slides will be deposited in the University of Montana Herbarium in Missoula. The other set of slides will be retained by Hannaea in Helena.

\section{RESULTS AND DISCUSSION}

Results are presented in Tables $4-6$, located near the end of this report following the Literature Cited section. Spreadsheets containing completed diatom proportional counts, with species' pollution tolerance classes and percent abundances, are attached as Appendix A. 


\section{FIELD AND SAMPLE NOTES}

Big Dry Creek Site \#9. The periphyton sample from this site consisted mainly of plant roots. The stream here formed long pools of variable depth. The substrate was a mix of small gravels and silt. Macrophytes were present along the channel edges. Channel alterations and sediment accumulations were minimal. Point bars were active but with little long-term enlargement. The sinuosity was about 2.0-2.5. Banks were stable with good vegetative cover. (Field notes by warren Kellogg, NRCS, 8/23/00.)

Little Dry Creek above Highway 200. The sample from this site was very silty and was composed primarily of plant roots. About $20 \%$ of the diatom cells were empty. Branching was observed in Rhizoclonium, but it was rare. Two species of Oedogonium were present. The habitat score for this site (115.5) was 68\% of the maximum possible (Carol Endicott, MDEQ, personal communication).

\section{NON-DIATOM ALGAE}

\section{Big Dry Creek}

Big Dry Creek supported a mix of green algae, euglenoid algae (Euglena), diatoms, and cyanobacteria (formerly called blue-green algae) (Table 4). Eight genera of non-diatom algae were present, which is less than the average number (13) recorded for reference streams in Great Plains Montana (Bahls 1993).

Diatoms were the most abundant algae, followed by greens, cyanobacteria, and euglenoids. Dominance by diatoms and greens and the occasional cell of Euglena indicate moderate nutrient enrichment and organic loading at this site. Nitrogen-fixing cyanobacteria cannot compete successfully with diatoms and greens under such conditions.

Anabaena was one of three nitrogen-fixing cyanobacteria in Big Dry Creek. Under certain conditions, Anabaena can produce waterblooms that release neurotoxins into the water. These toxins can be lethal to livestock, pets, and wildife. However, 
Anabaena was not abundant enough in Big Dry Creek to pose a problem for livestock producers.

\section{Little Dry Creek}

The sample from Little Dry Creek also contained a mix of green algae, diatoms, euglenoid algae, and cyanobacteria. Only five genera of non-diatom algae were present.

Diatoms dominated the sample from Little Dry Creek, followed by green algae, cyanobacteria, and euglenoids. Euglena, a good indicator of organic loading, was rare at this site.

Big Dry Creek and Little Dry Creek had only three genera of non-diatom algae in common: Oedogonium, Euglena, and Phormidium. The absence of Anabaena and the abundance of the filamentous green alga Rhizoclonium indicates that Little Dry Creek probably had cooler water and more water movement than did Big Dry Creek. It should also be noted that the sample from Little Dry Creek was collected in the spring, when higher flows and cooler waters are to be expected. The sample from Big Dry Creek was collected in late summer of a particularly dry year (2000).

\section{DIATOMS}

\section{Big Dry Creek}

The major diatom species in Big Dry Creek were all somewhat tolerant to very tolerant of nutrient enrichment, organic loading, and elevated dissolved solids (Table 5).

The dominant diatom in Big Dry Creek was Navicula duerrenbergiana. This diatom has been reported mainly from brackish seas and coastal waters in Europe and Israel (Krammer 
and Lange-Bertalot 1986). In Montana, Navicula duerrenbergiana is most common in silty praixie streams, including the lower reaches of the Redwater and Musselshell Rivers (unpublished data). In the Southern Fort Union Coal Region, this taxon has been reported from the lower reaches of Armells, Mizpah, Pumpkin, and Rosebud Creeks, where it prefers warm, brackish waters and tolerates some suspended sediment and turbidity (Bahls et al. 1984).

Next in abundance in Big Dry Creek was Diploneis puella. This diatom prefers brackish waters with muddy bottoms. Next in abundance was Navicula recens. In Europe, N. recens is common in brackish waters and in large rivers, such as the Rhein and the Weser (Krammer and Lange-Bertalot 1986).

Also common in Big Dry Creek, and to a lesser extent in Little Dry Creek, was Nitzschia palea. This diatom is very tolerant of organic loading and of low levels of dissolved oxygen. It is a good indicator of nitrogen enrichment.

\section{Little Dry Creek}

Diploneis puella--the diatom that prefers brackish waters with muddy bottoms--was also a major diatom species in Little Dry Creek (Table 5). However, also abundant here were Achnanthes minutissima and Cymbella affinis. Both of these diatoms prefer cool, flowing waters and do not tolerate heavy organic loading or low concentrations of dissolved oxygen. They are sensitive to pollution and are the dominant diatoms in many mountain streams of central and western Montana (unpublished data). 


\section{BIOASSESSMENT}

PROTOCOL I

Most diatom association metrics for Big Dry Creek indicated good to excellent water quality and biological integrity when compared to least-impaired reference streams elsewhere in eastern Montana (Table 5). However, a very low pollution index resulted in a rating of fair biological integrity, moderate impairment, and only partial support of aquatic life uses.

The source of the organic loading that resulted in this low pollution index is unknown. It may be natural in origin, that is, internal organic loading resulting from the decay of aquatic plants. Or, it may originate from wastewater discharges upstream in the Jordan area. Or, most likely, it is a combination of these two sources.

A low species diversity index and a large siltation index indicated minor impairment yet good biological integrity and full support of aquatic life uses in Big Dry Creek. However, the siltation index was within one percentage point of the threshold for moderate impairment for a prairie stream. Such a rating would correspond to fair biological integrity and only partial support of aquatic life uses.

All diatom metrics indicated full support of aquatic life uses in Little Dry Creek when compared to other prairie streams (Table 5). Only a slightly depressed pollution index resulted in a rating of good rather than excellent biological integrity. Little Dry Creek proved to be a suitable local reference stream for use in Protocol II. 
PROTOCOL II

The index of similarity between the two streams was 36.86 (Table 6), indicating that the study stream (Big Dry Creek) shared only about a third of its diatom association with the local reference stream (Little Dry Creek). Normally, such a low similariy index would indicate that some perturbation had caused the the diatom association of Big Dry Creek to be quite different (from that of Little Dry Creek) and that the stream had been moderately impaired. However, the two streams were sampled at different times of the year. Since the abundance of diatom species is highly seasonal, sampling in different seasons may explain much of the floristic difference between the two streams.

When compared to metric values for Little Dry Creek, the pollution and siltation indexes for Big Dry Creek indicated only minor impairment, good biological integrity, and full support of aquatic life uses. The diatom species diversity index was within the range of no impairment and excellent biological integrity when compared to Little Dry Creek. 


\section{LITERATURE CITED}

APHA. 1998. Standard Methods for the Examination of Water and Wastewater. 20th Edition. American Public Health Association, Washington, D.C.

Bahls, L.L. 1979. Benthic diatom diversity as a measure of water quality. Proc. Mont. Acad. Sci. 38:1-6.

Bahls, L.L. 1980. Salinity and The Structure of Benthic Algae (Periphyton) Communities in Streams of the Southern Fort Union Region, Montana. Environmental Sciences Division, Montana Department of Health and Environmental Sciences, Helena.

Bahls, L.L. 1993. Periphyton Bioassessment Methods for Montana Streams (Revised). Montana Department of Health and Environmental Sciences, Helena.

Bahls, L.L., Bob Bukantis, and Steve Tralles. 1992. Benchmark Biology of Montana Reference Streams. Montana Department of Health and Environmental Sciences, Helena.

Bahls, L.L., E.E. Weber, and J. O. Jarvie. 1984. Ecology and Distribution of Major Diatom Ecotypes in the Southern Fort Union Coal Region of Montana. U.S. Geological Survey Professional Paper 1289, U.S. Government Printing Office, washington.

Barbour, M.T., J. Gerritsen, B.D. Snyder, and J.B. Stribling. 1999. Rapid Bioassessment Protocols for Use in Streams and Wadeable Rivers: Periphyton, Benthic Macroinvertebrates and Fish. Second Edition. EPA/841-B-99-002. U.S. EPA, Office of Water, Washington, D.C.

Dillard, G.E. 1999. Common Freshwater Algae of the United States. J. Cramer, Berlin.

Johansen, J.R. 1999. Diatoms of Aerial Habitats. Chapter 12 in Stoermer, E.F., and J.P. Smol (eds.), The Diatoms, Cambridge University Press, New York.

Karr, J.R., and D.R. Dudley. 1981. Ecological perspectives on water quality goals. Environmental Management 5:55-69.

Klarich, D.A., and S.M. Regele. 1980. Structure, General Characteristics, and Salinity Relationships of Benthic Macroinvertebrate Associations in Streams Draining the Southern Fort Union Coalfield Region of Southeastern Montana. Environmental Sciences Division, Montana Department of Health and Environmental Sciences, Billings. 
Krammer, K., and H. Lange-Bertalot. 1986. Bacillariophyceae, Part 2, Volume 1: Naviculaceae. In Ettl, H., J. Gerloff, H. Heynig, and D. Mollenhauer (eds.), Freshwater Flora of Midale Europe. Gustav Fischer Publisher, New York.

Krammer, K., and H. Lange-Bertalot. 1988. Bacillariophyceae, Part 2, Volume 2: Bacillariaceae, Epithemiaceae, Surirellaceae. In Ettl, H., J. Gerloff, H. Heynig, and D. Mollenhauex (eds.), Freshwater Flora of Middle Europe. Gustav Fischer Publisher, New York.

Krammer, K., and H. Lange-Bertalot. 1991a. Bacillariophyceae, Part 2, Volume 3: Centrales, Fragilariaceae, Eunotiaceae. In Ettl, H., J. Gerloff, H. Heynig, and D. Mollenhauer (eds.), Freshwater Flora of Middle Europe. Gustav Fischer Publisher, Stuttgart.

Krammer, K., and H. Lange-Bertalot. 1991b. Bacillariophyceae, Part 2, Volume 4: Achnanthaceae, Critical Supplement to Navicula (Lineolatae) and Gomphonema, Complete List of Literature for Volumes 1-4. In Ettl, H., G. Gartner, J. Gerloff, H. Heynig, and D. Mollenhauer (eds.), Freshwater Flora of Middle Europe. Gustav Fischer Publisher, Stuttgart.

Lange-Bertalot, Horst. 1979. Pollution tolerance of diatoms as a criterion for water quality estimation. Nova Hedwigia $64: 285-304$.

Lange-Bertalot, Horst. 1993. 85 Neue Taxa Und Uber 100 Weitere Neu Definierte Taxa Erganzend Zur Susswasserflora Von Mitteleuropa Vol. 2/1-4. Bibliotheca Diatomologica, Band 27. J. Cramer, Berlin.

Lowe, R.L. 1974. Environmental Requirements and Pollution Tolerance of Freshwater Diatoms. EPA-670/4-74-005.

McFarland, B.H., B.H. Hill, and W.T. Willingham. 1997. Abnormal Fragilaria spp. (Bacillariophyceae) in streams impacted by mine drainage. Jour. of Freshwater Ecology 12(1):141-149.

Omernik, J.M., and A.L. Gallant. 1987. Ecoregions of the West Central United States (map). U. S. Environmental Protection Agency, Corvalis, Oregon.

Palmer, C.M. 1977. Algae and Water Pollution: An Illustrated Manual on the Identification, Significance, and Control of Algae in water Supplies and in Polluted water.

EPA $-600 / 9-77-036$.

Patrick, Ruth, and C.W. Reimer. 1966. The Diatoms of The United States Exclusive of Alaska and Hawaii. Volume 1:

Fragilariaceae, Eunotiaceae, Achnanthaceae, Naviculaceae. 
Monograph Number 13, The Academy of Natural Sciences, Philadelphia.

Patrick, Ruth, and C.W. Reimer. 1975. The Diatoms of The United States Exclusive of Alaska and Hawaii. Volume 2, Part 1: Entomoneidaceae, Cymbellaceae, Gomphonemaceae, Epithemiaceae. Nonograph Number 13, The Academy of Natural Sciences, Philadelphia.

Plafkin, J.L., M.T. Barbour, K.D. Porter, S.K. Gross, and R.M. Hughes. 1989. Rapid Bioassessment Protocols for Use in Rivers and Streams: Benthic Macroinvertebrates and Fish. EPA 440-4-89-001.

Prescott, G.W. 1978. How to know the Freshwater Algae. Third Edition. Wm. C. Brown Company Publishers, Dubuque, Iowa.

Renfro, H.B., and D.E. Feray. 1972. Geological Highway Map of the Northern Rocky Mountain Region. American Association of Petroleum Geologists, Tulsa, Oklahoma.

Smith, G.M. 1950. the Fresh-Water Algae of The United States. McGraw-Hill Book Company, New York.

Stevenson, R.J., and I.L. Bahls. 1999. Periphyton Protocols. Chapter 6 in Barbour, M.T., J. Gerritsen, B.D. Snyder, and J.B. Stribling. Rapid Bioassessment Protocols for Use in Streams and Wadeable Rivers: Periphyton, Benthic Macroinvertebrates and Fish. Second Edition. EPA/841-B-99002. U.S. EPA, Office of Water, Washington, D.C.

Stevenson, R.J., and Y. Pan. 1999. Assessing Environmental Conditions in Rivers and Streams with Diatoms. Chapter 2 in Stoermer, E.F., and J.P. Smol (eds.), The Diatoms:

Applications for the Environmental and Earth Sciences. Cambridge University Press, New York.

USDA. 1976. Climax Vegetation of Montana (map). U. S. Department of Agriculture, Soil Conservation Service, Cartographic Unit, Portland.

Whitford, L.A., and G.J. Schumacher. 1984. A Manual of FreshWater Algae (Revised). Sparks Press, Raleigh, North Carolina.

Whittaker, R.H. 1952. A study of summer foliage insect communities in the Great Smoky Mountains. Ecological Monographs 22:1-44.

Woods, A.J., Omernik, J.M., Nesser, J.A., Shelden, J., and Azevedo, S.H. 1999. Ecoregions of Montana (color poster 



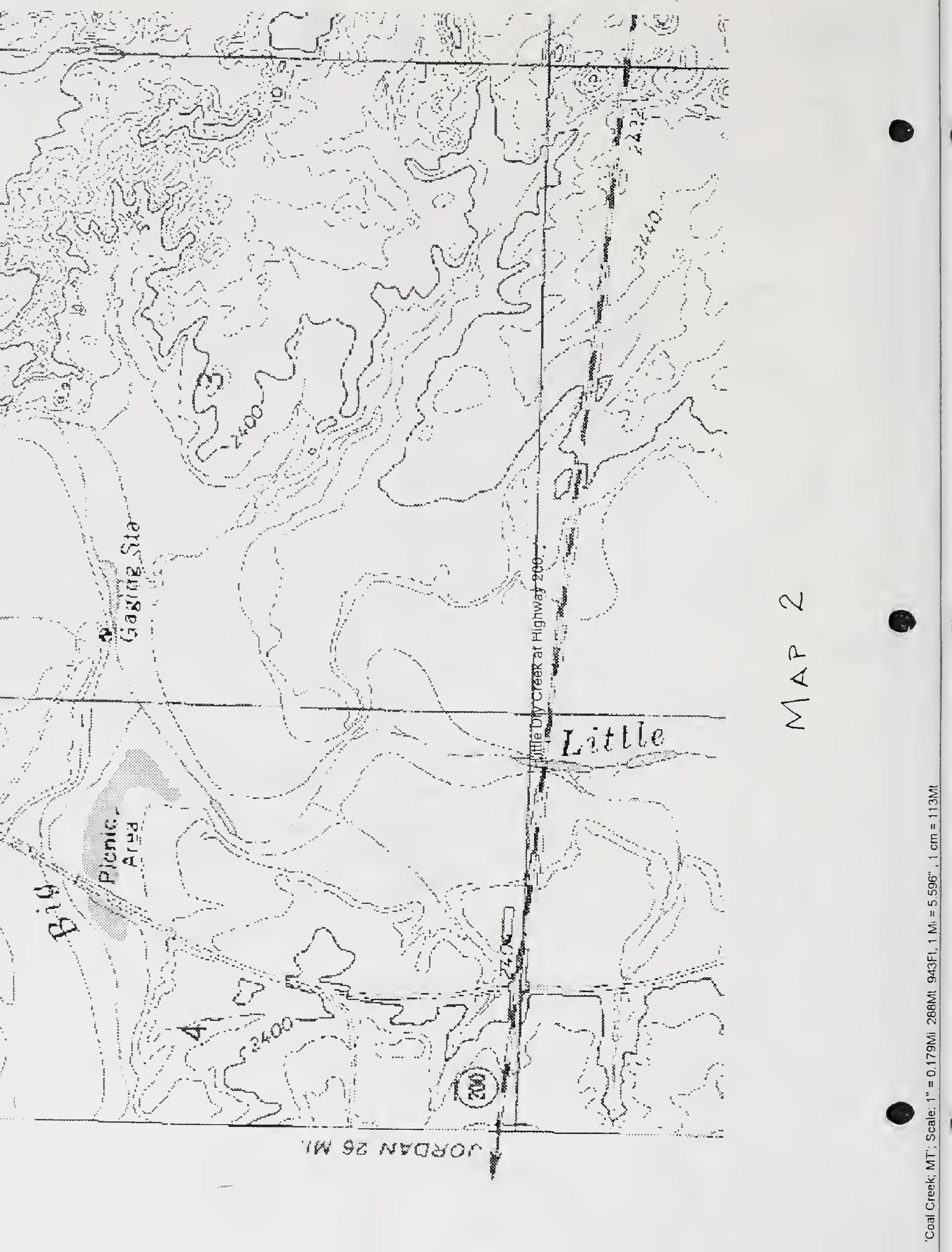


Table 1. Location of periphyton stations on Big Dry Creek and Little Dry Creek near Jordan, Montana: Station codes, sample numbers in the Montana Diatom Database, sample dates, and legal descriptions.

Location

Station

Code

\section{Sample} Number
Sample

Date
Legal

Description

Big Dry Creek at Monte Billing Place Site \#9 $1987-01 \quad 8 / 23 / 00$ T20NR42E34DB above ford

Little Dry Creek at Highway 200

L. Dry 0745-02 5/27/99 TI8NR42E09AA












Table 4. Relative abundance of cells and rank by biovolume of diatoms and genera of non-diatom algae in periphyton samples collected from Big Dry Creek and Little Dry Creek near Jordan, Montana.

Taxa

Relative Abundance and (Rank)

Big Dry Creek

$(8 / 23 / 00)$
Little Dry Creek

$(5 / 27 / 99)$

Chlorophyta (green algae)

Ankistrodesmus

Bulbochaete

Cosmarium

Oedogonium

Rhizoclonium

Spirogyra occasional (8)

occasional (3)

occasional (4)

common (2)

Erequent (3)

abundant (2)

frequent (4)

rare (6) occasional (9) abundant

(1)

Cyanophyta (cyanobacteria)

Anabaena

Calothrix

Phormidium frequent (1)

Euglenophyta (euglenoid algae)

Euglena

Bacillariophyceae

Chrysophyta (golden algae)

occasional (6)

occasional (7)

occasional (5)

common (5)

1 Formerly known as blue-green algae. 
Table 5. Percent abundance of major diatom species ${ }^{1}$ and values of selected diatom association metrics for periphyton samples collected from Big Dry Creek and Little Dry Creek near Jordan, Montana.

\begin{tabular}{|c|}
\hline $\begin{array}{l}\text { Species/Metric } \\
\text { (Pollution Tolerance Class }\end{array}$ \\
\hline $\begin{array}{l}\text { Achnanthes minutissima (3) } \\
\text { Cymbella affinis (3) } \\
\text { Diploneis puella (2) } \\
\text { Entomoneis paludosa (2) } \\
\text { Gomphonema parvulum (1) } \\
\text { Navicula duerrenbergiana } \\
\text { Navicula recens (2) } \\
\text { Nitzschia frustulum (2) } \\
\text { Nitzschia palea (1) }\end{array}$ \\
\hline $\begin{array}{l}\text { Cells Counted } \\
\text { Total Species } \\
\text { Species Counted } \\
\text { Species Diversity } \\
\text { Percent Dominant Species } \\
\text { Disturbance Index } \\
\text { Pollution Index } \\
\text { Siltation Index } \\
\text { Percent Abnormal Cells } \\
\text { Percent Epithemiaceae } \\
\text { Similarity Index }\end{array}$ \\
\hline
\end{tabular}

Percent Abundance/Metric Values
Big Dry Creek $(8 / 23 / 00)$
Little Dry Creek $(5 / 27 / 99)$

(3)

(1)

\begin{tabular}{rr} 
& 9.35 \\
16.99 & 7.61 \\
1.33 & 17.71 \\
6.19 & 5.49 \\
21.72 & 0.25 \\
11.89 & 0.37 \\
5.83 & \\
9.22 & $0^{4}$ \\
412 & 8.48 \\
48 & \\
45 & 401 \\
3.90 & 68 \\
21.72 & 66 \\
0.00 & 4.82 \\
1.56 & 17.71 \\
69.66 & 9.35 \\
\hline 0.00 & 2.01 \\
1.09 & 37.14 \\
& 0.00 \\
\hline
\end{tabular}

36.86

1 A major diatom species is here considered to be one that accounts for $5 \%$ or more of the cells in one or more samples of a sample set.

2 Underlined values indicate good biological integrity, minor impairment, and full support of aquatic life uses; bold values indicate fair biological integrity, moderate impairment, and partial support of aquatic life uses; all other values indicate excellent biological integrity, no impairment, and full support of aquatic life uses when compared to diatom criteria for mountain and plains streams in Tables 3 and 4 .

33 = sensitive to pollution; 2 = tolerant of pollution; 1 = most tolerant of pollution.

4 A "p" indicates that the taxon was recorded as present during a preliminary floristic scan of the diatom slide, but it was not encountered during the diatom proportional count. 
Table 6. Metric scores and impairment ratings for Big Dry Creek based on a comparison with Little Dry Creek, following Protocol II and Table 12 in Bahls (1993). Underlined values indicate full support of aquatic life uses, minor impairment, and good biological integrity; bold values indicate partial support of aquatic life uses, moderate impairment, and fair biological integrity; all other values indicate full support of aquatic life uses, no impairment, and excellent biological integrity.

Metric

Metric Score

$(\%)$

Shannon Diversity Index

80.91

Pollution Index

77.61

Siltation Index

$\underline{53.32}$

Similarity Index

36.86 
APPENDIX A: DIATOM PROPORTIONAL COUNTS 


\begin{tabular}{|c|c|c|c|c|}
\hline Sample & Genus/speciesf Variety. & Pollution Tolefance Class & Count & Percent \\
\hline \multicolumn{2}{|c|}{198701 Amphora veneta } & 1 & 0! & 0.00 \\
\hline \multicolumn{2}{|c|}{198701 Caloneis bacillum } & 2 & 1 & 0.12 \\
\hline \multicolumn{2}{|c|}{198701 Caloneis schumanniana } & 2 & 5 & 0.61 \\
\hline \multicolumn{2}{|c|}{198701 Cyclotella meneghiniana } & 2 & 1 & 0.12 \\
\hline \multicolumn{2}{|c|}{198701 Cymbella pusilla } & 1 & 2 & 0.24 \\
\hline \multicolumn{2}{|c|}{198701 Cymbella silesiaca } & 2 & 6 & 0.73 \\
\hline \multicolumn{2}{|c|}{ 198701 Diploneis puella } & 2 & 140 & 16.99 \\
\hline \multicolumn{2}{|c|}{198701 Entomoneis alata } & 2 & 1 & 0.12 \\
\hline \multicolumn{2}{|c|}{198701 Entomoneis paludosa } & 2 & 11 & 1.33 \\
\hline \multicolumn{2}{|c|}{198701 Gomphonema gracile } & 2 & 2 & 0.24 \\
\hline \multicolumn{2}{|c|}{198701 Gomphonema parvulum } & 1 & 51 & 6.19 \\
\hline \multicolumn{2}{|c|}{198701 Gyrosigma spencerii } & 2 & 0 & 0.00 \\
\hline \multicolumn{2}{|c|}{198701 Navicula ammophila } & 2 & 1 & 0.12 \\
\hline \multicolumn{2}{|c|}{198701 Navicula capitata } & 2 & 0 & 0.00 \\
\hline \multicolumn{2}{|c|}{198701 Navicula caterva } & 2 & 7 & 0.85 \\
\hline \multicolumn{2}{|c|}{ 19870) Navicula cincta } & 1 & 6 & $0 . \overline{73}$ \\
\hline \multicolumn{2}{|c|}{198701 Navicula cryptotenella } & 2 & 2 & 0.24 \\
\hline \multicolumn{2}{|c|}{198701 Navicula duerrenbergiana } & 1 & 179 & 21.72 \\
\hline \multicolumn{2}{|c|}{198701 Navicula erifuga } & 2 & 24 & 2.91 \\
\hline \multicolumn{2}{|c|}{198701 Navicula omissa } & 1 & 4 & 0.49 \\
\hline \multicolumn{2}{|c|}{ 198701 Navicula pupula } & 2 & 4. & 0.49 \\
\hline \multicolumn{2}{|c|}{ 198701 Navicula pygmaea } & 2 & 2 & 0.24 \\
\hline 198701 & Navicula recens & 2 & 98 & 11.89 \\
\hline 198701 & Navicula tenelloides & 1 & 9 & 1.09 \\
\hline 198701 & Navicula veneta & 1 & 21 & 2.55 \\
\hline 198701 & Neidium ampliatum & 3 & 1 & 0.12 \\
\hline 198701 & Nitzschia amphibia & 2 & 8 & 0.97 \\
\hline 198701 & Nitzschia archibaldii & 2 & 3 & 0.36 \\
\hline 198701 & Nitzschia clausii & 2 & 2. & 0.24 \\
\hline 198701 & Nitzschia filiformis & 2 & 17 & 2.06 \\
\hline 198701 & Nitzschia frustulum & 2 & 48 & 5.83 \\
\hline 198701 & Nitzschia gracilis & 2 & 3 & 0.36 \\
\hline 198701 & Nitzschia incognita & 2 & 2 & 0.24 \\
\hline 198701 & Nitzschia liebetruthii & 2 & 4 & 0.49 \\
\hline 198701 & Nitzschia lorenziana & 2 & 2 & 0.24 \\
\hline 198701 & Nitzschia microcephala & 1 & 4 & 0.49 \\
\hline 198701 & Nitzschia palea & 1 & 76 & 9.22 \\
\hline 198701 & Nitzschia paleacea & 2 & 2 & 0.24 \\
\hline 198701 & Nitzschia reversa & 2 & 32 & 3.88 \\
\hline 198701 & Nitzschia solita & 1 & 2 & 0.24 \\
\hline 198701 & Nitzschia valdestriata & 2 & 6 & 0.73 \\
\hline 198701 & Pleurosigma delicatulum & 2 & $6 !$ & 0.73 \\
\hline 198701 & Rhopalodia brebissonii & 1 & 4 & 0.49 \\
\hline 198701 & Rhopalodia gibba & 2 & 3 & 0.36 \\
\hline 198701 & Rhopalodia operculata & 1 & 2 & 0.24 \\
\hline 198701 & Surirella brebissonii & 2 & 6 & 0.73 \\
\hline 198701 & Synedra acus & 2 & 1. & 0.12 \\
\hline 198701 & Synedra delicatissima & 2 & 13 & 1.58 \\
\hline
\end{tabular}




\begin{tabular}{|c|c|c|c|}
\hline Genus/Species Nariety & Pollution Tolerance Class & Count & Percent \\
\hline 074502 Achnanthes minutissima & 3 & 75 & 9.35 \\
\hline 074502 Amphipleura pellucida & 2 & 9 & 1.12 \\
\hline 074502 Amphora dusenii & 2 & 4 & 0.50 \\
\hline 074502 Amphora inariensis & 3 & 2 & 0.25 \\
\hline 074502 Amphora libyca & 3 & 2 & 0.25 \\
\hline 074502 Caloneis bacillum & 2 & 2 & 0.25 \\
\hline 074502 Caloneis schumanniana & 2 & 6 & 0.75 \\
\hline 074502 Cylindrotheca gracilis & 2 & 4 & 0.50 \\
\hline 074502 Cymbella affinis & 3 & 61 & 7.61 \\
\hline 074502 Cymbella cymbiformis & 3 & 10 & 1.25 \\
\hline 074502 Cymbella microcephala & 2 & 27 & 3.37 \\
\hline 074502 Cymbella minuta & 2 & 3 & 0.37 \\
\hline 074502 Cymbella muelleri & 2 & 14 & 1.75 \\
\hline 074502 Cymbella pusilla & 1 & 6 & 0.75 \\
\hline 074502 Cymbella silesiaca & 2 & 1 & 0.12 \\
\hline 074502 Diatoma tenuis & 2 & 15 & 1.87 \\
\hline 074502 Diploneis pseudovalis & 2 & 10 & 1.25 \\
\hline 074502 Diploneis puella & 2 & 142 & 17.71 \\
\hline 074502 Entomoneis alata & 2 & 4 & 0.50 \\
\hline 074502 Entomoneis paludosa & 2 & 44 & 5.49 \\
\hline 074502 Fragilaria vaucheriae & 2 & 36 & 4.49 \\
\hline 074502 Gomphonema parvulum & 1 & 2 & 0.25 \\
\hline 074502 Gyrosigma spencerii & 2 & 2 & 0.25 \\
\hline 074502 Navicula accomoda & 1. & 1. & 0.12 \\
\hline 074502 Navicula capitata & 2 & 4 & 0.50 \\
\hline 074502 Navicula capitatoradiata & 2 & 1 & 0.12 \\
\hline 074502 Navicula caterva & 2 & 10 & 1.25 \\
\hline 074502 Navicula cincta & 1) & 5 & 0.62 \\
\hline 074502 Navicula cincta v. rostrata & 1 & 32 & 3.99 \\
\hline 074502 Navicula circumtexta & 1. & 1 & 0.12 \\
\hline 074502 Navicula cryptocephala & 3 & 2 & 0.25 \\
\hline 074502 Navicula cryptotenella & 2 & 16 & 2.00 \\
\hline 074502 Navicula Cuspidata & 2 & 4 & 0.50 \\
\hline 074502 Navicula duerrenbergiana & 1 & 3 & 0.37 \\
\hline 074502 Navicula erifuga & 2 & 13 & 1.62 \\
\hline 074502 Navicula gregaria & 2 & 5 & 0.62 \\
\hline 074502 Navicula minuscula & 1 & 7 & 0.87 \\
\hline 074502 Navicula notha & 2 & 3 & 0.37 \\
\hline 074502 Navicula odiosa & 1 & 2 & 0.25 \\
\hline 074502 Navicula reichardtiana & 2 & 2 & 0.25 \\
\hline 074502 Navicula veneta & 1 & 5 & 0.62 \\
\hline 074502 Navicula viridula $v$. rostellata & 2 & 3 & 0.37 \\
\hline 074502 Nitzschia amphibia & 2 & 8 & 1.00 \\
\hline 074502 Nitzschia apiculata & 2 & 10 & 1.25 \\
\hline 074502 Nitzschia bergii & 1 & 8 & 1.00 \\
\hline 074502 Nitzschia filiformis & 2 & 7 & 0.87 \\
\hline 074502 Nitzschia frustulum & 2 & 0 & 0.00 \\
\hline
\end{tabular}




\begin{tabular}{|l|r|r|r|}
\hline Sample Genus/Species Nariefy & Pollution Tolerance Class & Cownt & Percemt \\
\hline 074502 Nitzschia frustulum v. subsalina & 2 & 5 & 0.62 \\
\hline 074502 Nitzschia gracilis & 2 & 4 & 0.50 \\
\hline 074502 Nitzschia levidensis & 2 & 4 & 0.50 \\
\hline 074502 Nitzschia microcephala & 1 & 6 & 0.75 \\
\hline 074502 Nitzschia palea & 1 & 68 & 8.48 \\
\hline 074502 Nitzschia paleacea & 2 & 21 & 2.62 \\
\hline 074502 Nitzschia perminuta & 3 & 2 & 0.25 \\
\hline 074502 Nitzschia perspicua & 1 & 5 & 0.62 \\
\hline 074502 Nitzschia recta & 3 & 3 & 0.37 \\
\hline 074502 Nitzschia reversa & 2 & 4 & 0.50 \\
\hline 074502 Nitzschia sigma & 2 & 2 & 0.25 \\
\hline 074502 Nitzschia solita & 1 & 0 & 0.00 \\
\hline 074502 Nitzschia valdestriata & 2 & 6 & 0.75 \\
\hline 074502 Pinnularia microstauron & 2 & 4 & 0.50 \\
\hline 074502 Rhoicosphenia curvata & 3 & 4 & 0.50 \\
\hline 074502 Simonsenia delognei & 2 & 4 & 0.50 \\
\hline 074502 Stauroneis tackei & 2 & 2 & 0.25 \\
\hline 074502 Stephanodiscus hantzschii & 2 & 6 & 0.75 \\
\hline 074502 Surirella brebissonii & 2 & 16 & 2.00 \\
\hline 074502 Synedra delicatissima v. angustiss & 2 & 1 & 0.12 \\
\hline 074502 Synedra fasciculata & 2 & 2 & 0.25 \\
\hline
\end{tabular}

